\title{
Computer-based solar tracking system for PV energy yield improvement
}

\author{
Rini Nur Hasanah ${ }^{1}$, Aditya Bagus Setyawan ${ }^{2}$, Eka Maulana ${ }^{3}$, Tri Nurwati ${ }^{4}$, Taufik $^{5}$ \\ 1,2,3,4 Electrical Engineering, Department, Faculty of Engineering, Brawijaya University, Indonesia \\ ${ }^{5}$ Electrical Engineering Department, Cal Poly State University, USA
}

\section{Article Info \\ Article history: \\ Keywords: \\ Energy demand \\ Energy yield \\ Monitoring \\ Optimization \\ Solar tracking}

Received Sep 17, 2019

Revised Dec 12, 2019

Accepted Feb 13, 2020

\begin{abstract}
Electric energy is the main driver of various daily activities, both to increase productivity as well as to improve life quality. Energy demand is continuously increasing in parallel to the progress in technology and population growth. Depletion of fossil energy sources and awareness of environmental protection make people resort to renewable energy sources like solar energy. Low efficiency and intermittent characteristic of solar energy may originate from the sun movement along the day as well as the year. Efforts have always been tried to deal with the drawbacks. This paper proposes a computer-based tracking system to fully monitor and control a solar panel movement. The designed system has proven a good performance of working at certain time intervals, either hourly, or even continuously, as desired. Energy yield improvement has been achieved by processing the tracking results with the help of a microcontroller to optimize the power generation of the solar panel.
\end{abstract}

This is an open access article under the CC BY-SA license.

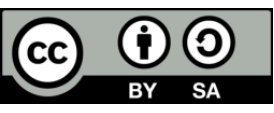

\section{Corresponding Author:}

Rini Nur Hasanah,

Electrical Engineering, Department, Faculty of Engineering,

Brawijaya University,

Jalan MT Haryono 167 Malang 65145 Indonesia.

Email: rini.hasanah@ub.ac.id

\section{INTRODUCTION}

Electric energy is vital to power various equipments. It makes people enjoy the life comfort and industry increase the productivity. Inspite being considered as an emerging world economic power, the energy consumption of Indonesia is still relatively lower than the neighbouring economic power [1]. Access to electricity is greatly differed, being as high as $99.99 \%$ in the western part of the country, while as low as $59.84 \%$ in the eastern part of the country $[1,2]$.

As a part of its contribution to global climate change reduction, Indonesia makes a great effort to meet its commitment under the Paris agreement. Benefitted from its strategic location around the equator, Indonesia also tries to have recourse to solar energy to fulfill its continuously increasing energy demand and to improve the electrification ratio. Harnessing solar energy can be accomplished using either a simple and low-cost system for the low-scale capacity or even more complex systems. However, the conversion efficiency is in general still quite low. The efficiency currently used in implementation is in the range of $6 \%$ $30 \%$, while the highest record achieved in 2015 was $46 \%$, based on the PV Efficiency Chart regularly updated and published by National Renewable Energy Laboratory (NREL) in Colorado, USA.

One important way to improve the energy yield of solar power generation, which means its efficiency, is the addition of solar tracker to find the maximum power point condition as given on the PV profile characteristics [3-11]. Even though it has been considered less effective because of the power 
consumption for the actuating motor, an efficiency improvement up to $32 \%$ had been achieved using the single-axis trackings [3, 9-11], or even up to $40 \%$ when using the dual-axis trackings [4, 12-14], being compared to the use of static system. The single-axis tracking could improve the yearly energy yield around $20-25 \%$ [15], even up to $25.2 \%$ [16] more than using a fixed-utility $[17,18]$.

The addition of tracking system to enhance the energy yield has also been related to some direct application fields, like in wireless sensor network [14], green-house system [5], and sometimes being combined with the maximum power-point algorithms [19-20], and the use of artificial intelligence theories [8]. Microcontroller has normally been used to implement the control algorithms [5, 19, 21-24]. Some control algorithms have been based on calculation of the sun geometry to determine the position, while others benefitted sensors as output tuning to trim the azimuth and altitude angles [13, 20, 25-26].

This paper describes a contribution to the PV energy yield improvement using a computer-based single-axis tracking system to monitor and control a solar panel movement. The Riemann sum method [2730] has been implemented to compute the energy yield based on the tracking results. The Riemann sum method is working by approaching the integration operation using the discretization and summation of total area underneath a curve on a graph [29]. The time interval between the beginning and the end of the data acquisition is divided into $n$ subintervals, which are used as the Riemann rectangles [28]. The Riemann sum method has also been used to validate the experiment data in a shipboard microgrids under various quasibalanced and unbalanced voltage conditions [30]. A comparison of the tracking results has been made to the results of a static solar panel. The testing and measurement were done both on the static and tracking modes based on the choice made using the computer program.

\section{RESEARCH METHOD}

The method used to achieve the research goal includes the design and construction of the system, the testing and measurement, and the data analysis. The system design comprises the software design and the hardware design.

\subsection{Diagram of the system}

The diagram of the designed system is given in Figure 1. As seen, the computer/PC was designed to be the master of all systems, whereas the microcontroller ran only what the computer commanded. The obtained sensor data went into the microcontroller, then were sent to the computer via TTL USB and displayed on the Delphi Solar Panel Time Changer application. The battery control regulator (BCR) considered in this study, was a $12 \mathrm{~V}$ or $24 \mathrm{~V}$ system, which had a maximum rating current of $20 \mathrm{~A}, 11.1 \mathrm{~V}$ over discharge protection and $17 \mathrm{~V}$ over charge protection.

The solar panel base used was designed of $\pm 160 \mathrm{~cm} \times 140 \mathrm{~cm} \times 40 \mathrm{~cm}$ dimension, being capable of supporting two solar panels with a capacity of $100 \mathrm{Wp}$ each, weighing $\pm 10 \mathrm{~kg}$. The solar panel was driven by an actuator with a current rating between 0.2-0.8 without load, and 0.2-3.2 with load. The actuator was capable of lifting loads up to $50 \mathrm{~kg}$, and moving objects with a static weight of up to $250 \mathrm{~kg}$.

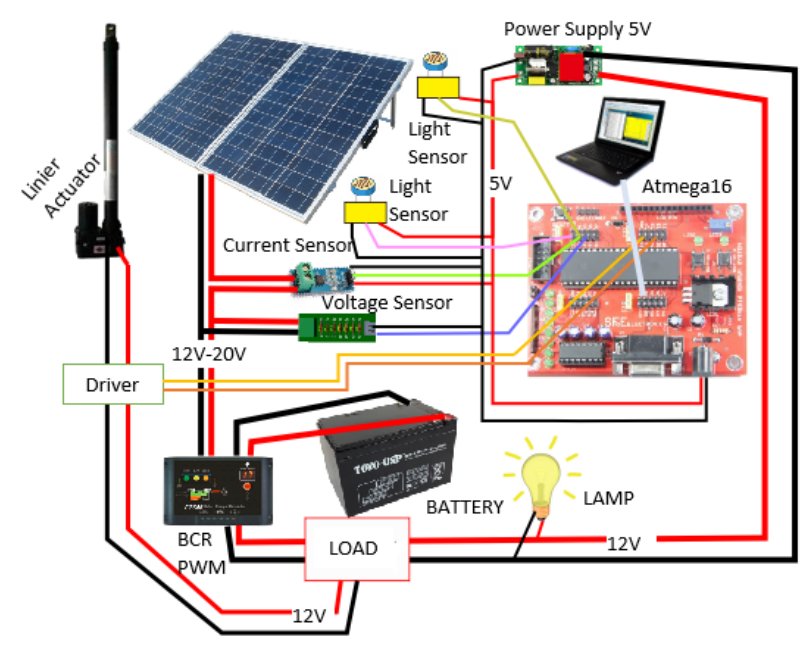

Figure 1. The diagram of the designed system 


\subsection{Software design}

The functioning of the microcontroller and the Delphi application are given in Figure 2. As indicated, the functioning of the designed system has been based on the interface software on the Delphi Borland system, the Atmega-16 minimum system as the processor of sensor input-output data, and the controller of motor driver.

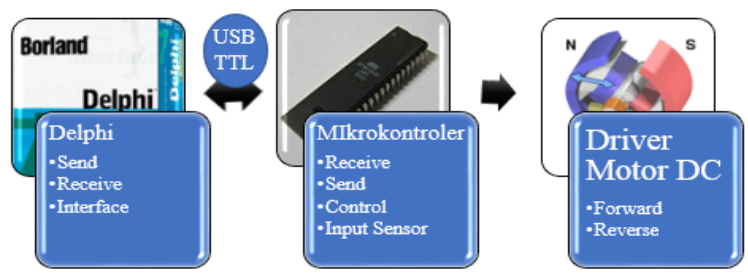

Figure 2. The functioning of microcontroller and Delphi application to actuate motor

Each of the Delphi applicaton and microcontroller had their own respective performance. They were interconnected via USB through their related Tx, Rx, and ground. Prolific USB Serial Adapter has been used as the driver of the USB TTL. The Delphi worked as an interface and master, while the microcontroller worked as the processor of sensors data and control the switch of motor driver.

The software design includes the design of interface program on the Delphi Borland application system and the design of the microcontroller program to process the sensor input-output data using CVAVR application. The Delphi program was Windows OS-based, as it was run on PC. The flowchart of the computer programming is given in Figure 3, whereas that of the microcontroller programming is shown in Figure 4.
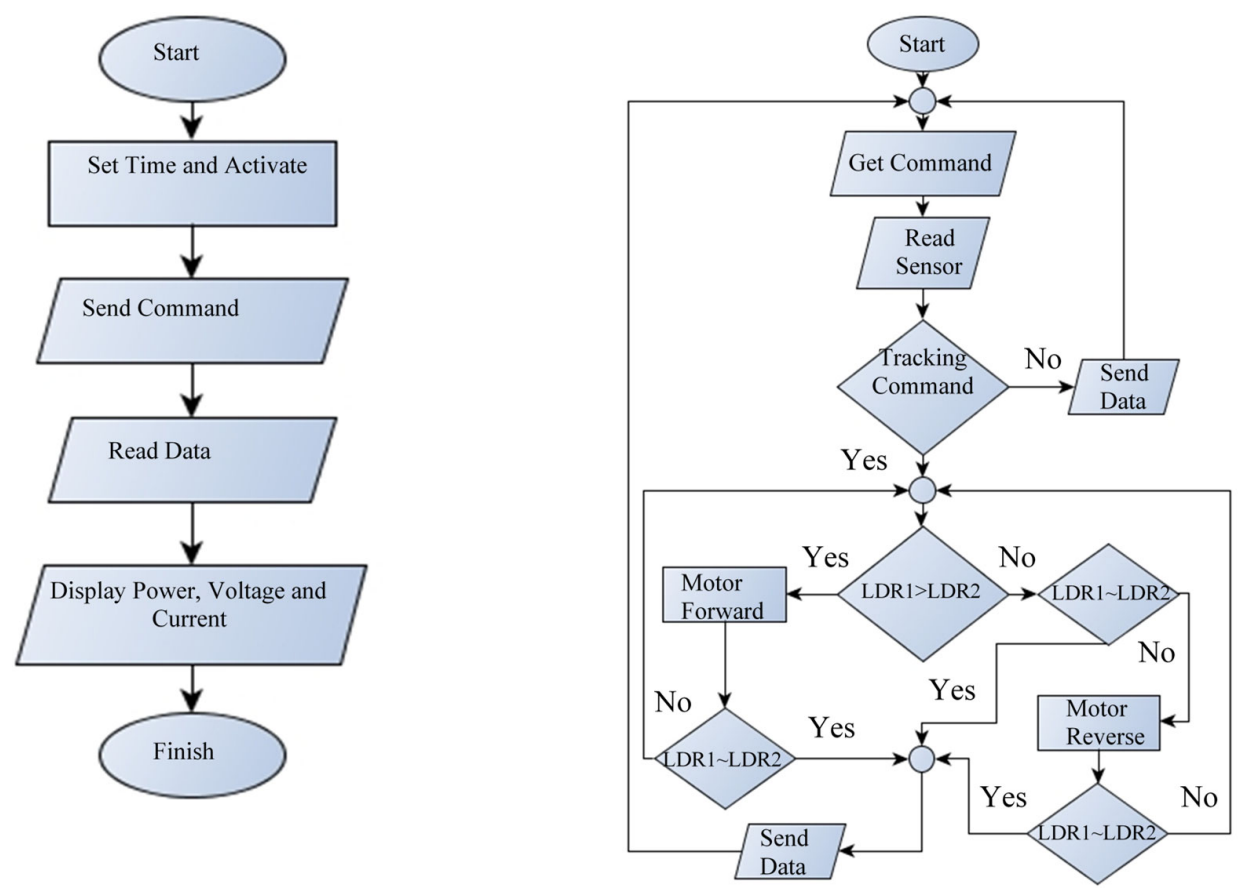

Figure 3. Flowchart of the computer programming Figure 4. Flowchart of the microcontroller programming

The Delphi interface has been divided into three Tabsheets, as seen in Figure 5. The first Tabsheet (a) has been used as the homepage, where the user could control the time the solar panel to be moved. 
The second Tabsheet (b) has been used as the power graphic feature, which would display power graphic after the activation of microcontroller, sensors and the Delphi application. The resulted data could be stored and opened using Microsoft Excel program for further process. The third Tabsheet (c) has been used as the manual control feature, which was made so that the solar panels could be moved as desired.

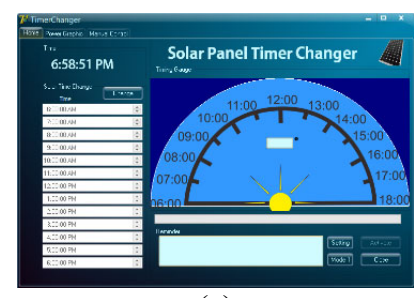

(a)

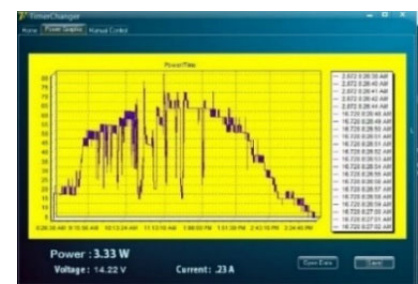

(b)

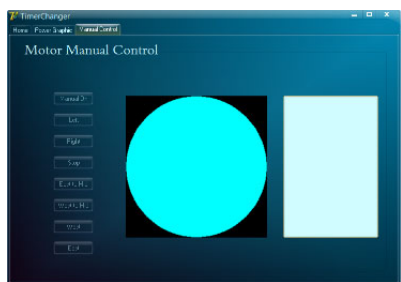

(c)

Figure 5. Delphi interface, (a) homepage control, (b) power graphic feature, (c) manual control feature

\subsection{Simulation of the Whole System Design}

The whole system comprises the unification of the hardware design and the supporting software design. It has been simulated using the Proteus software and by connecting the Delphi application. The simulation circuit design using Proteus software is given in Figure 6.

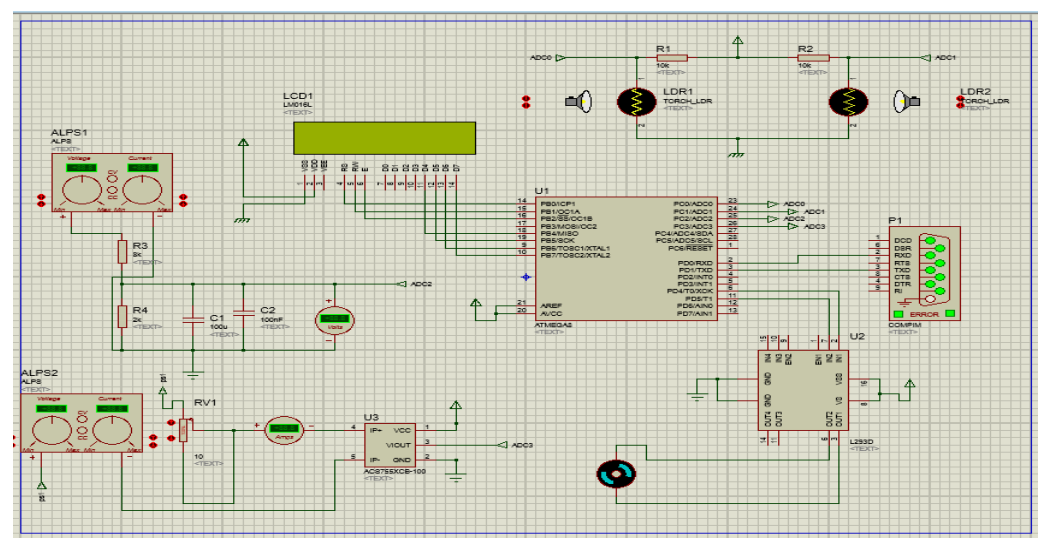

Figure 6. The whole system circuit design using Proteus software simulation

Delphi program took the role as the user interface to determine the timing of microcontroller activating to drive motor. Motor was to be activated based on the ADC data received by LDR. Two LDR sensors were installed to detect the highest solar intensity. Motor was stopped once the optimized solar intensity was found. Proteus simulated the function of hardware components such as microcontroller, sensors, motor driver, and DC motor.

\section{RESULTS AND DISCUSSION}

\subsection{Program setting}

Experiment has been done by connecting all components of Figure 1. Solar Panel Time Changer was used to set-up the Setting and adjust the port into Prolific USB TTL Serial Port, as seen in Figure 7, connecting the Delphi application to the microcontroller. After the connection of all components has been succeeded, activating the Setting made the program work to monitor the current, voltage and power generated by the solar panel. Based on the chosen time interval, the system modul changed the position according to the solar intensity captured by the LDR sensors. 


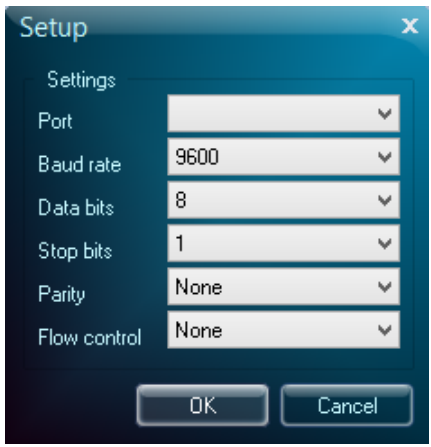

Figure 7. Set-up setting

\subsection{Motor power consumption}

Motor to actuate the tracking system has been tested by operating it in no-load and under load conditions. Solar panel has been used as motor load. The results of motor loading experiment are given in Table 1.

Table 1. The power usage by motor

\begin{tabular}{lcc}
\hline \multicolumn{1}{c}{ Variable } & No-load condition & Loading condition \\
\hline Power (watt) & $2.4-5.4$ & $4-9$ \\
Current (ampere) & $0.2-0.3$ & $0.23-0.75$ \\
Voltage (volt) & $12-18$ & $12-19$ \\
\hline
\end{tabular}

As indicated by Table 1 , the power consumed by motor was relatively small, as motor was not the main actuator. It has been used only in the hydraulic fluid pump of the actuator.

\subsection{Tracking experiment}

The static condition of solar panel was facing northwards at an angle of about $30^{\circ}$. The tracking condition has been started with initial position of facing eastwards. The tracking experiment has been done by considering three different positions of the solar panel; facing southwards, facing northwards, and during the tracking from east to west direction. The power generated by the solar panel is given in Table 2 . The data have been taken in Bantur village, Malang regency of East Java province, with the earth coordinates of $8^{\circ} 18^{\prime} 29.7^{\prime \prime} \mathrm{N} 112^{\circ} 34^{\prime} 41.0^{\prime \prime} \mathrm{E}$. The temperature during the experiment was around $24^{\circ}-33^{\circ} \mathrm{C}$. The altitude of the location was $360 \mathrm{~m}$ above sea level.

Table 2. The power generated by solar panel

\begin{tabular}{|c|c|c|c|c|c|}
\hline Time & $\begin{array}{c}\text { Power } \\
\text { generated by } \\
\text { static solar } \\
\text { panel }\end{array}$ & $\begin{array}{c}\text { Power } \\
\text { generated by } \\
\text { tracked solar } \\
\text { panel }\end{array}$ & Time & $\begin{array}{c}\text { Power } \\
\text { generated by } \\
\text { static solar } \\
\text { panel }\end{array}$ & $\begin{array}{c}\text { Power } \\
\text { generated by } \\
\text { tracked solar } \\
\text { panel }\end{array}$ \\
\hline $09: 52: 59$ & 53.77 & 47.43 & $13: 30: 09$ & 57.9 & 50.78 \\
\hline $10: 10: 38$ & 40.21 & 50.48 & $13: 40: 46$ & 53.72 & 56.62 \\
\hline $10: 20: 01$ & 56.94 & 50.18 & $13: 50: 35$ & 57.56 & 57.58 \\
\hline $10: 30: 03$ & 60.66 & 50.48 & $14: 00: 44$ & 53.72 & 40.44 \\
\hline $10: 41: 23$ & 20.68 & 29.96 & $14: 10: 36$ & 49.59 & 45.24 \\
\hline $10: 50: 02$ & 43.43 & 76.84 & $14: 20: 44$ & 41.2 & 37.02 \\
\hline $10: 57: 47$ & 23.02 & 78.15 & $14: 31: 54$ & 33.3 & 36.81 \\
\hline $11: 11: 23$ & 53.77 & 82.72 & $14: 40: 56$ & 29.23 & 36.4 \\
\hline $11: 14: 48$ & 53.17 & 64.34 & $14: 51: 32$ & 25.09 & 36.6 \\
\hline $11: 51: 06$ & 79.8 & 81.34 & $15: 01: 14$ & 13.97 & 32.17 \\
\hline $12: 12: 17$ & 66.8 & 78.15 & $15: 11: 41$ & 14.06 & 31.43 \\
\hline $12: 15: 37$ & 62.87 & 73.62 & $15: 21: 07$ & 14.06 & 19.65 \\
\hline $12: 30: 51$ & 24.93 & 71.14 & $15: 31: 40$ & 13.88 & 31.62 \\
\hline $12: 40: 36$ & 62.87 & 66.8 & $15: 41: 48$ & 10.34 & 27.5 \\
\hline $12: 52: 11$ & 62.87 & 63.24 & $15: 51: 29$ & 6.8 & 15.44 \\
\hline $13: 01: 47$ & 62.87 & 67.58 & $15: 59: 20$ & 3.33 & 3.75 \\
\hline $13: 10: 26$ & 62.5 & 70.73 & $15: 59: 21$ & 3.33 & 3.75 \\
\hline $13: 21: 36$ & 62.13 & 66.02 & & & \\
\hline
\end{tabular}

Computer-based solar tracking system for PV energy yield improvement (Rini Nur Hasanah) 
Table 2 shows that power generated by solar panels in static condition was good enough, and also indicated that the solar panel was in good position to receive the coming sunlight. However, the tracked solar panel resulted in higher generated power, as in this condition the solar panels receive longer sunlight.

\subsection{Comparison of static panel and tracked panel}

The graphical results of generated power under the static panel condition facing southwards, facing northwards, and using the tracked solar panel, are given in Figure 8.

Using the tracking system, the generated power could be increased or optimized. This optimization would result in more generated power per day. The optimization percentage could be found out using (1).

$$
\text { Optimization }(\%)=\frac{P_{\text {tracker }}-\left(P_{\text {static }}+P_{\text {motor }}\right)}{\left(P_{\text {motor }}+P_{\text {static }}\right)} \times 100 \%
$$

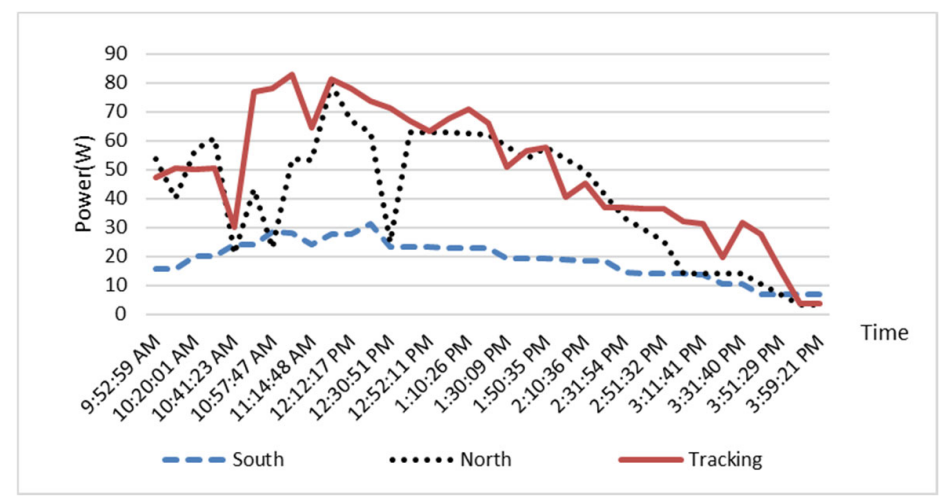

Figure 8. Comparison between static panel and tracked panel results

Using (1), the resulted optimization of the generated power is given in Figure 11.

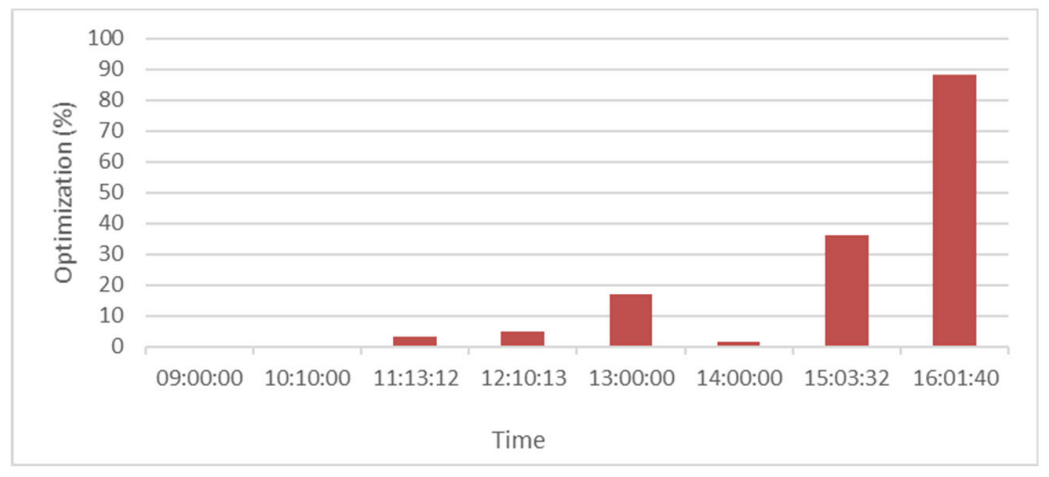

Figure 9. Graphical results of the generated power optimization

As shown in Figure 9, at 09:00:00 and 10:10:00 there were no power optimization because at those moments the solar panels tracking would face eastwards but not be completely illuminated because of the wall shadow on the testing site. In the afternoon the solar panels would face northwards and started not getting sunlight, making the power value dropped. However, under the tracking position the panel still got sunlight, so the optimized value was quite large.

To find out the produced energy per day, the obtained power value should be multiplied by the time during which the solar panel was working. Under the tracking position, the value must be reduced by the energy consumed by the motor and microcontroller. The total generated energy per day has been approximated using the Riemann sum method, giving the optimized generated energy per day [27-30].

Int J Pow Elec \& Dri Syst, Vol. 11, No. 2, June 2020 : 743 - 751 
The implementation of the Riemann sum method on the graphical results of generated power using the static panel and that using the tracked panel are given in Figure 10 and 11 consecutively.

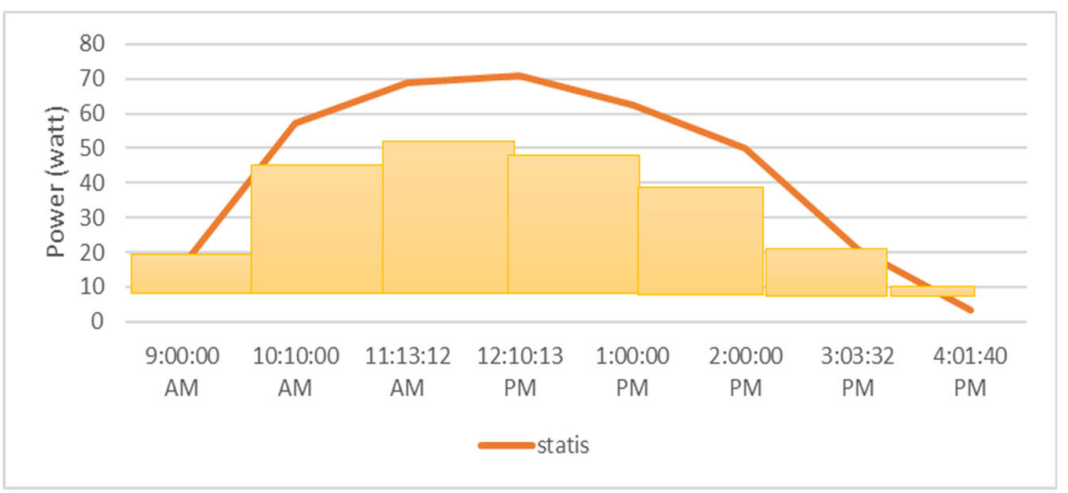

Figure 10. Riemann sum method on the generated power using the static panel

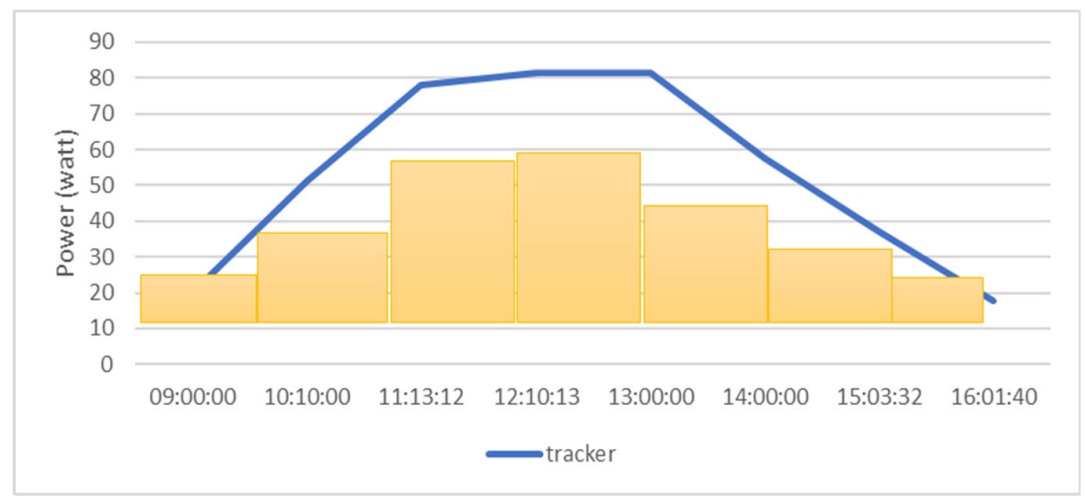

Figure 11. Riemann sum method on the generated power using the tracked panel

As seen in Figure 10 and 11, the linear regression made the power values look more stable with no drastic, but gradual drop or increase of power. The step-by-step calculation results of the daily produced energy is shown in Table 3. Based on Table 3, comparing the total generated energy using the static panel and the tracked panel resulted in the optimization as much as $16.51 \%$.

Table 3 . Total energy generated by the panel

\begin{tabular}{|c|c|c|}
\hline Time & Using static panel & Using tracked panel \\
\hline $09.00-10.00$ & 15.99 & 51.08 \\
\hline $10.00-11.00$ & 57.26 & 78.15 \\
\hline $11.00-12.00$ & 68.77 & 81.34 \\
\hline $12.00-13.00$ & 70.73 & 81.34 \\
\hline $13.00-14.00$ & 62.5 & 57.58 \\
\hline $14.00-15.00$ & 53.4 & 36.99 \\
\hline $15.00-16.00$ & 20.88 & 17.58 \\
\hline Total & $352.86 \mathrm{~W}$-day & $424.05 \mathrm{~W}$-day \\
\hline
\end{tabular}

\section{CONCLUSION}

The use of a computer-based tracking system made the observation of the power produced by solar panels and the data storing easier. The use of a linear actuator as a driver was the right choice because of the small power usage by the motor. The motor could be controlled with an Atmega16-controlled H-Bridge circuit, and a time changer solar panel program as the master mind. The performance of the tracking system was quite good, because the tracking system enabled the solar panel receive sunlight longer than when it was

Computer-based solar tracking system for PV energy yield improvement (Rini Nur Hasanah) 
in a static condition. When using a single-axis tracking, there was an increase in generated energy compared to static solar panel, meaning an optimization of solar power production.

\section{REFERENCES}

[1] Kirari J.K., et al, "Supporting Indonesia's renewable energy development in remote and rural areas through innovative funding," Indonesia Development Forum 2018. Jakarta, pp. 10-11 Jul 2018.

[2] PwC Indonesia Power Industry Survey-APLSI, "Alternating currents: Indonesian power industry survey 2018," July 2018-2nd edition. Jakarta: PT Pricewaterhouse Coopers Indonesia. 2018.

[3] Kitaeva M.V., et al, "Solar tracker," Siberian Journal of Science, vol. 3, no. 4, 2012.

[4] Smirnov A.A, et al, "Designing integrated PV facility with dual-axis solar tracking system mounted on the south building face," IEEE Conferences, Chelyabinsk: South Ural State University, Russian Federation, pp. 1-4, 2017.

[5] Sharma V., Tayal V.K, "Hardware implementation of sun tracking solar panel using 8051-microcontroller," 2017 6th International Conference on Reliability, Infocom Technologies and Optimization (Trends and Future Directions) (ICRITO), pp. 483-486, 2017.

[6] Nanda L., Dasgupta A., Rout U.K., "Smart solar tracking system for optimal power generation," $20173 \mathrm{rd}$ International Conference on Computational Intelligence \& Communication Technology (CICT), pp. 1-5, 2017.

[7] Das S., Sadhu P., Pal N., Mukherjee S, "Single axis automatic solar tracking system using microcontroller, Indonesian Journal of Electrical Engineering and Computer Science, vo. 12, no. 12, pp. 8028-8032, 2014.

[8] Hasanah R.N., Putri S.I., Suyono H, "Optimization of sun-tracker positioning using takagi-sugeno fuzzy-logic method," Applied Mechanics and Materials, vol. 785, pp. 231-235, 2015.

[9] Whavale S, Dhavalikar M., "A review of adaptive solar tracking for performance enhancement of solar power plant," Proceedings of the 2018 IEEE International Conference on Smart City and Emerging Technology (ICSCET), Mumba, India, pp. 1-8, 2018.

[10] Sharma A, Vaidya V, Jamuna K., "Design of an automatic solar tracking controller: Solar tracking controller," Proceedings of the 2017 IEEE International Conference on Power and Embedded Drive Control (ICPEDC), Chennai, India, pp. 505-510, 2017.

[11] Mohaimin AH, et al, "Design and fabrication of single-axis and dual-axis solar tracking systems, "Proceedings of the 2018 IEEE Student Conference on Research and Development (SCOReD), Selangor, Malaysia, pp. 1-4, 2018.

[12] Salama HAE, Taha ATM, "Practical implementation of dual axis solar power tracking system," Proceedings of the 2018 IEEE Twentieth International Middle East Power Systems Conference (MEPCON), Cairo, Egypt, pp. 446-451, 2018.

[13] Mustafa FI, et al, "Direct and indirect sensing two-axis solar tracking system," Proceedings of the 2017 IEEE 8th International Renewable Energy Congress (IREC), Amman, Jordan, pp.1-4, 2017.

[14] Sanjaya J, et al, "Implementation of solar tracking system to maximize energy absorption in wireless sensor network," Proceedings of the 2018 10th International Conference on Information Technology and Electrical Engineering (ICITEE), pp. 577-580, 2018.

[15] Zhang Q-X., Yu H-Y., Zhang Q-Y., Zhang Z-Y. Shao C-H., Yang D, “A solar automatic tracking system that generates power for lighting greenhouses,” Energies, vol. 8, pp. 7367-7380, 2015.

[16] Salasovich J., et al, "Feasibillity study of economics and performance photovoltaics. NREL," TP-7A40-58480, 2013.

[17] Jalil SM, et al, "Design of maximum power point tracking for solar collector drying system: An experimental study," International Journal of Power Electronics and Drive Systems (IJPEDS), vol. 9, no. 4, pp. 1799-1803,2018.

[18] Abdulrazzaq AA, Ali AH., "Efficiency performances of two MPPT algorithms for PV system with different solar panels irradiances," International Journal of Power Electronics and Drive Systems (IJPEDS), vol. 9, no. 4, pp. 1755-1764, 2018.

[19] Arif EMH, et al, "An efficient microcontroller-based sun tracker control for solar cell systems," International Journal of Electrical and Computer Engineering (IJECE), vol. 9, no. 4, Part I, pp. 2743-2750,2019.

[20] Yoganandini AP, Anitha GS, "A cost effective computational design of maximum power point tracking for photovoltaic cell," International Journal of Electrical and Computer Engineering (IJECE), vol. 9, no. 2, pp. 851-860, 2019.

[21] Kassem A, Hamad M., "A microcontroller-based multi-function solar tracking system," Proceedings of the 2011 IEEE International Systems Conference, Montreal, QC, Canada, pp. 13-16, 2011.

[22] Lokesh A, et al, "Solar Tracking System using Microcontroller," Proceedings of the 2018 International Conference on Inventive Research in Computing Applications (ICIRCA), pp. 1094-1098, 2018.

[23] Stjepanović A, et al, "Microcontroller based solar tracking system," Proceedings of the 2009 IEEE 9th International Conference on Telecommunication in Modern Satellite, Cable, and Broadcasting Services, Nis, Serbia, pp. 518-521, 2009.

[24] Morón C, et al, "New prototype of photovoltaic solar tracker based on arduino," Energies, vol. 10, no. 9, pp. 1298, 2017.

[25] Zuhal ER, Marangozoglu, S., "New design for solar panel tracking system based on solar calculations," Proceedings of the 2018 IEEE 61st International Midwest Symposium on Circuits and Systems (MWSCAS). Windsor, ON, Canada, pp. 1042-1045, 2018.

Int J Pow Elec \& Dri Syst, Vol. 11, No. 2, June 2020 : $743-751$ 
[26] Xing Z., "Research and design of control system of the solar panel tracking," Proceedings of the 2016 IEEE Advanced Information Management, Communicates, Electronic and Automation Control Conference (IMCEC), Xi'an, China, pp. 1384-1388, 2016.

[27] Masarova R, Kurnatova J., "Generalized Riemann integral in the analysis of dynamic systems," Proceeedings of the 2012 15th International Conference on Interactive Collaborative Learning (ICL). Villach, Austria, pp. 1-3, 2012.

[28] Su C-L, Chen C-J, Lee C-C., "Fast Evaluation Methods for Voltage Sags in Ship Electrical Power Systems," IEEE Transactions on Industry Applications, vol. 49, no. 1, pp. 233-241, 2013.

[29] Etiene T, Jönsson D, Ropinski T, Scheidegger C, Comba JLD, Nonato LG, Kirby RM, Ynnerman A, Silva CT, "Verifying Volume Rendering Using Discretization Error Analysis," IEEE Transactions on Visualization and Computer Graphics, vol. 20, no. 1, pp. 140-154, 2014.

[30] Liu W, Tarasiuk T, Su C-L, Gorniak M, Savaghebi M, Vasquez JC, Guerrero JM., "An Evaluation Method for Voltage Dips in a Shipboard Microgrid Under Quasi-Balanced and Unbalanced Voltage Conditions," IEEE Transactions on Industrial Electronics, vol. 66, no. 10, pp. 7683-7693, 2019. 